\title{
ICZM and WTP of stakeholders for beach conservation: policymaking suggestions from an Italian case study
}

\author{
Silva MARZETTI DALL'Aste BRANDOLINI \\ School of Economics, Management and Statistics, University of Bologna, \\ Piazza Scaravilli 2, 40126, Bologna, Italy.E-mail: silva.marzetti@unibo.it. \\ MARTA DisEgNA \\ School of Economics and Management, Free University of Bolzano, Piazza dell'Università, \\ 39100 Bolzano, Italy. E-mail: marta.disegna@unibz.it.
}

\begin{abstract}
In accordance with integrated coastal zone management (ICZM), private stakeholders could be asked to pay for the benefits from beach conservation projects. Since a private contribution is measured by the amount of other goods a person is willing to give up for beach quality, it can be solicited in monetary terms or, when possible, in other forms, such as specific works. In this paper, by analysing the results of two surveys in Italy concerning stakeholders' perceptions of ICZM and their willingness to pay for these benefits, suggestions for beach management are provided to policymakers. One survey focuses on beach visitors who are asked to pay in monetary terms, while the other focuses on sunbathing establishment managers, who are asked to pay not only in monetary terms but also through beach works. The results show that the majority of these stakeholders are fully or partially aware of what ICZM is, and are unwilling to pay. However, regression analysis of those willing to pay suggests that promoting an information and education campaign about ICZM may be important if stakeholders' probability of paying is to be increased.
\end{abstract}

Keywords: integrated coastal zone management; contingent valuation method; visitors; sunbathing establishment managers; beach conservation

\footnotetext{
The authors are most grateful to the referees for their helpful comments and suggestions. EU support through research project INTERREG IIIC, BEACHMED-e, 2006-2008, sub-project ICZM-MED, is gratefully acknowledged. We thank Ing. Carlo Albertazzi and Dott. Roberto Montanari of the Assessorato Sicurezza Territoriale, Difesa del Suolo e della Costa, Protezione Civile of the EmiliaRomagna Regional Council for the materials provided about the regional ICZM and, in particular, for Figures 1 and 2 (by Ing. Mentino Preti). We are indebted to Barbara Zanuttigh for her collaboration in creating Figure 3. The survey instruments and further data description are available on request.
} 
Policymakers are increasingly stimulated to implement coastal defence projects according to integrated coastal zone management (ICZM) principles. Nevertheless, few published studies provide original data about the perceptions of ICZM of private stakeholders and their willingness to pay (WTP) in monetary terms for coastal conservation, while there seem to be no studies on other forms of payment, such as specific works.

This study focuses on ICZM perception by private stakeholders in the EmiliaRomagna region of Italy, and whether they are willing to pay voluntarily for the implementation of a project for beach conservation when public funds are scarce. The study is funded by the EU research project INTERREG IIIC, BEACHMED-e (Strategic Management of Beach Protection Measures for the Sustainable Development of the Mediterranean Coastal Areas), 2006-2008, sub-project ICZM-MED (Concerted Actions, Tools and Criteria for the Implementation of Integrated Coastal Zone Management in the Mediterranean). A specific aim of sub-project ICZM-MED is to collect data about ICZM in specific study areas of certain Mediterranean regions in order to improve regional, national and Mediterranean integrated coastal management policies.

Following the recommendations of the EU, the Emilia-Romagna Regional Council, involved in this research, published guidelines in 2005 for the regional ICZM (Regional Law No 645, 20/01/2005), while the implementation of the first public investments according to these guidelines started in 2006. In this region access to the coast (mainly consisting of sandy beaches) is traditionally free of charge (Regione Emilia-Romagna, 2006) thus respecting the recommendation of the Council of Europe (1997, pp 2-4) and the Protocol on ICZM in the Mediterranean (European Union, 2009, p 25), while coastal defence projects have traditionally been financed through public funds. However, public funds are increasingly scarce, and private stakeholders may be asked to pay for conservation projects.

In this region the Riccione and Misano Adriatico sites are chosen as case studies. The focus is on two particular categories of stakeholders in whom the Regional Council is particularly interested: beach visitors and sunbathing establishment managers who provide beach services to visitors. Therefore, two questionnaire surveys were carried out in these sites in 2007, one of beach visitors and the other of sunbathing establishment managers in order to ascertain their ICZM perception and WTP for beach conservation. As regards the contribution issue, the contingent valuation method (CVM) is applied. These stakeholders are asked their WTP for non-marketable benefits, such as indirect beach use, option values and non-use values, from a conservation project the aim of which is to restore the beach eroded by the sea. Beach visitors are asked to pay in monetary terms, while sunbathing establishment managers are asked to pay in monetary terms or through specific beach works.

Before describing the site and the conservation project, the existing literature on ICZM and CVM is reviewed. The economic benefits ascribed to a beach are highlighted, and stakeholders' behavioural models are presented. The survey designs and descriptive statistics are shown. Finally, two regression models are applied: a two-stage model (Probit and OLS) for the results relating to visitors, and a hurdle count model (Probit and zero-truncated Poisson) for those relating to managers. Our conclusions highlight the fact that the majority of stakeholders considered are fully or partially informed about what ICZM is, but are 
unwilling to pay. Regression analysis of those who are willing to pay shows that the more stakeholders know about ICZM, their probability of paying is higher.

\section{ICZM: definition and literature}

Integrated management of coastal areas may be defined as a 'multidisciplinary process that unites levels of government and the community, science and management, sectorial and public interests in preparing and implementing a programme for the protection and the sustainable development of coastal resources and environments' (Sorensen, 2002, pp 1-4). ICZM programmes are a political response to the demand for sustainable coastal development, according to which the coast is a whole system in which different human uses are interdependent, and conflicts between them have to be resolved. The World Bank (1996) published guidelines for the implementation of these programmes. Highlighting the importance of informing the public in addressing human activities in order to achieve ICZM, it has assisted some developing countries in their coastal management (Huber and Jameson, 2000).

A rational ICZM plan has to ensure that the environment and landscapes are managed in harmony with economic, social and cultural development. In particular, economic activities, such as coastal tourism, have to be developed according to ICZM objectives and principles. Rupprecht Consult-Forthung Beratung $\mathrm{GmbH}$ and International Ocean Institute (2006) consider ICZM at a national institutional level, and show that in 2006, among Mediterranean countries, Malta, France, Slovenia and Spain were making progress in implementing a national ICZM strategy, while the other countries had no national strategy. Two other studies deal with the institutional issues concerning ICZM in Egypt (Nasr et al, 1997) and Turkey (Akyarh et al, 1997). Ioppolo et al (2013), instead, apply ICZM to a sustainable eco-tourism programme for a coastal site in Italy.

A general ICZM principle is to ensure appropriate governance 'allowing adequate and timely participation in a transparent decision-making process by local populations and stakeholders in civil society concerned with coastal zones' (EU, 2009, L34/21). A variety of stakeholders, such as economic operators and visitors, are interested in benefits from coastal resources. According to ICZM they have to be empowered to pay for their conservation not only for the satisfaction of their own needs but also for those of future generations. More specifically, Article 21 of the PROTOCOL (EU, 2009, L34/25) states that, in order to implement plans and programmes, 'appropriate measures to adopt relevant economic, financial and/or fiscal instruments intended to support local, regional, national initiatives for the integrated management of coastal zones' may be taken. Therefore, in a situation of scarcity of public funds, a policymaker needs to know (a) how stakeholders perceive ICZM, (b) how many stakeholders are actually willing to pay for supporting an ICZM project, (c) how much they are willing to pay and (d) the variables determining their WTP. Koutrakis et al (2011) provide some descriptive statistics about private stakeholders' ICZM perception and WTP for defence projects by comparing the results of surveys by questionnaire carried out in five Mediterranean regions (including the Emilia-Romagna region). They highlight that beach visitors generally have 


\begin{tabular}{|c|c|c|c|c|c|}
\hline Source & Country & $\begin{array}{l}\text { Economic } \\
\text { value }\end{array}$ & $\begin{array}{l}\text { Payment } \\
\text { vehicle }\end{array}$ & $\begin{array}{l}\text { Relevant } \\
\text { population }\end{array}$ & Mean WTP \\
\hline $\begin{array}{l}\text { Silberman and } \\
\text { Klock (1988) }\end{array}$ & USA & $\begin{array}{l}\text { Beach existence } \\
\text { value }\end{array}$ & OTVC $^{a}$ & Beach visitors & US\$16 \\
\hline $\begin{array}{l}\text { Silberman et al } \\
\text { (1992) }\end{array}$ & USA & $\begin{array}{l}\text { Beach existence } \\
\text { value }\end{array}$ & OTVC & $\begin{array}{l}\text { Residents: V } \\
\text { and NVF. } \\
\text { Beach visitors: } \\
\text { V and NVF }\end{array}$ & $\begin{array}{l}\text { US } \$ 15 \text { and } \\
\text { US } \$ 9 ; \text { US } \$ 19 \\
\text { and US } \$ 9.5\end{array}$ \\
\hline $\begin{array}{l}\text { Goodman et al } \\
(1996)\end{array}$ & UK & $\begin{array}{l}\text { Coastal } \\
\text { conservation } \\
\text { values }\end{array}$ & Annual tax & General public & $£ 48$ \\
\hline $\begin{array}{l}\text { Spash et al } \\
(2000)\end{array}$ & $\begin{array}{l}\text { Curacao; } \\
\text { The } \\
\text { Maldives }\end{array}$ & $\begin{array}{l}\text { Coral reefs } \\
\text { non-use values }\end{array}$ & AWTPc & General public & $\begin{array}{l}\text { US } \$ 2.08 ; \\
\text { US } \$ 3.24\end{array}$ \\
\hline Subade (2005) & Philippines & $\begin{array}{l}\text { Coral reefs } \\
\text { non-use values }\end{array}$ & AWTP & Residents & $\begin{array}{l}\text { Values range from } \\
\text { US } \$ 2.89 \text { to } \\
\text { US } \$ 13.79\end{array}$ \\
\hline
\end{tabular}

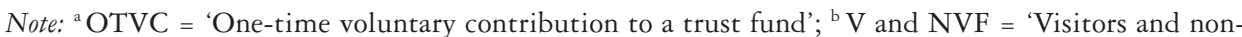
visitors in the future'; 'AWTP = 'Annual willingness to pay to a trust fund'.

little knowledge of ICZM, though a non-negligible number of them are willing to pay.

\section{CVM applied to coastal and marine conservation: existing literature}

In the literature we found CVM studies for estimating the WTP for coastal and marine conservation in monetary terms for both visitors and residents, while we found no previous study of WTP through beach works and for sunbathing establishment managers.

Table 1 summarizes the main characteristics of various CV studies. We note that Silberman and Klock (1988) and Silberman et al (1992) focus on the existence value of a beach, and that the results by Silberman et al (1992) show that those who would visit the beach state on average a higher WTP than those who would not visit it. Goodman et al (1996) evaluate conservation benefits in general, while Spash et al (2000) and Subade (2005) evaluate non-use values.

\section{Riccione and Misano Adriatico beaches: the defence project}

The coast of the Emilia-Romagna region (north west Adriatic sea) is about $130 \mathrm{~km}$ long, mainly consisting of wide beaches of fine light sand. Access to the beaches is free of charge. The regional tourist industry, one of the most important in Europe, is based on recreational beach activities (such as sunbathing, swimming and walking) mainly in spring and summer. Sunbathing establishment 


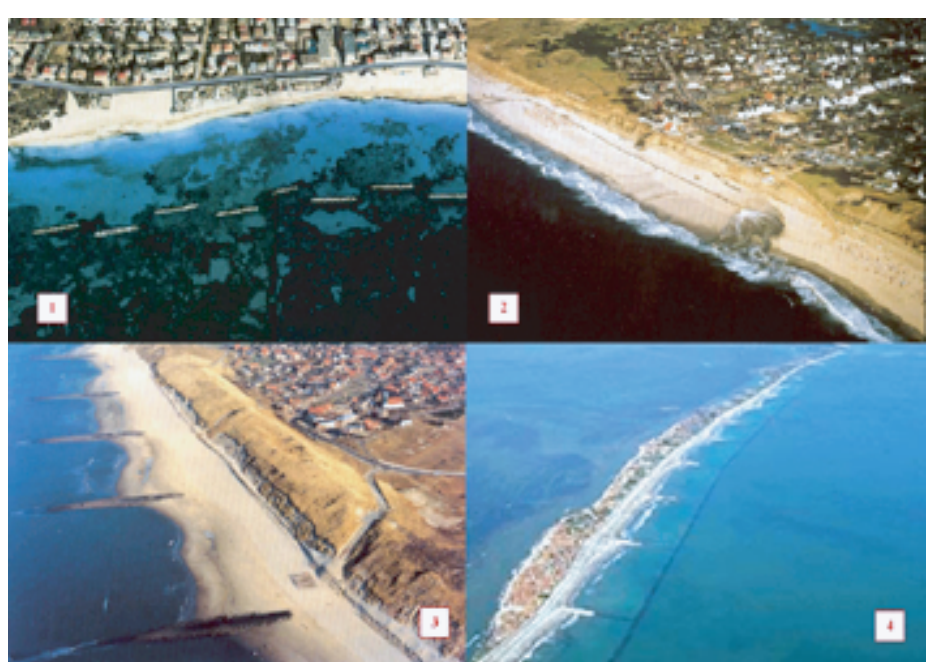

Figure 1. Four different kinds of defence structures. 1 - parallel breakwaters; 2 - nourishment; 3 - groynes; 4 - composite intervention.

managers provide facilities on the beaches, renting out sun umbrellas and loungers, cabins and boats, and providing bar and restaurant services. These managers pay a concession tax to the Italian government. Tourist arrivals (nationals and foreigners) are recorded officially, and are estimated to be about 5 million per year (http://rersas.regione.emilia-romagna.it). Day-visitors (nonresidents who come from the densely populated areas near the coast) are numerous, but they are not officially recorded. Since 1930, beaches in this region have been protected from the erosion caused by sand reduction from rivers and subsidence increase through the introduction of defence structures, which are now part of the coastal landscape. Figure 1 shows the main kinds of defence structures implemented. In particular, Figure 1.1 shows emerged/ submerged parallel breakwaters, Figure 1.2 pure nourishment, Figure 1.3 groynes and nourishment and Figure 1.4 a composite intervention of groynes, nourishment and submerged breakwaters. ${ }^{1}$ Pure nourishment is classified as soft structure, and the other techniques as hard structures. Visitors and sunbathing establishment managers are generally familiar with these structures.

Riccione and Misano Adriatico are well-developed coastal resorts in this region. There are about 34,800 residents in Riccione, and 10,000 in Misano Adriatico. Officially recorded tourist arrivals in 2007 amounted to 800,789 and in 2011 to 759,883 - of which 687,953 and 649,011, respectively, are in Riccione alone (http://www.provincia.rimini, accessed 8 January 2013). Since the survey results for beach visitors show that around $24 \%$ are day-visitors, and also considering residents (about 44,800), we estimate that about 1 million people may visit these two sites per year.

The Riccione and Misano Adriatico beaches are threatened by erosion. Nourishment (see Figure 1.2) was chosen as the defence project, the conservation benefits of which have to be evaluated. Nourishment consists in bringing marine sands - taken from a site off the coast - to the eroded beach in a 

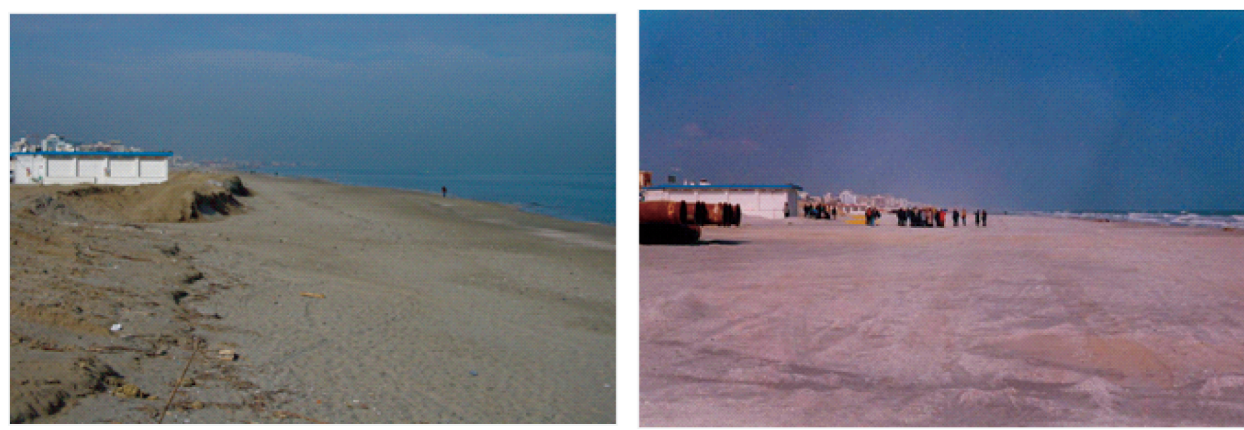

Figure 2. Riccione and Misano Adriatico beach: erosion.

Figure 3. Riccione and Misano Adriatico beach: nourishment.

quantity and of a quality such as to restore the beach; in this way the deficit of original sand created by erosion is replaced with a certain volume of other sand (Burcharth et al, 2007, pp 37-38). Therefore, nourishment (Figure 1.2) has a lower environmental impact than that of hard structures (see Figures 1.1, 1.3 and 1.4) but is of limited duration, since it mitigates the effects but not the causes of erosion. Thus the beach has to be periodically re-nourished at the beginning of spring. In these sites a nourishment project has a duration of five years, and costs about $€ 3.5$ million. It requires annual maintenance work. Figures 2 and 3 show the Riccione beach under erosion and after nourishment.

\section{Evaluation methods and design}

The questionnaires for visitors and sunbathing establishment managers had two parts, one for ICZM perception and one for WTP for the beach conservation benefits of the project. As regards the WTP part, a hypothetical market has to be created for conservation benefits; therefore we focus on the theoretical economic foundations of the evaluation of these benefits.

\section{The economic value of a beach}

According to ICZM, one of the tasks of a policymaker is to implement beach conservation projects in a sustainable way. According to the sustainability approach, the total economic value (TEV) of a beach is the sum of the values of its different economic benefits, such as present use value, option value and non-use values. Use value is the monetary amount ascribed to beach use by whoever makes the valuation, and may be distinguished in direct use value (DUV), such as informal recreational activities and fishing, and indirect use value (IUV), such as storm protection and flood control. When a person elicits a value for having the option of visiting the beach in the future, she or he makes reference to option value (OV). Non-use values are mainly distinguished in bequest value (BV) and existence value (EV) (Turner, 1999). BV measures the amount a 
person would pay for beach preservation for future generations; while EV is the amount the person who makes the valuation would pay only for knowing that the beach exists. TEV may depend on factors such as beach characteristics, degree of protection, how much people know about its true state, and the demand for its services. In general, conservation values are higher, the more non-replaceable beach services there are.

The values of the TEV which are not established by the market are DUV, when access to a beach is free of charge, and non-DUV - that is, IUV, OV and non-use values. The need to estimate these values or benefits 'stems from a belief that unless the value of natural resources is expressed in monetary units it will continue to be assigned a zero value, and will not therefore be incorporated into the decision making process' (King, 1995, p 130).

\section{Methods for estimating beach conservation values}

Different economic methods exist for evaluating the benefits from the conservation of a beach. One method is the procedure of the benefit transfer (BT), according to which time and money are saved by transferring the value of conservation benefits estimated through CVM for other sites (study sites) to another site (policy site). Its application requires site and population characteristics to be similar for both policy and study sites (Polomé et al 2005). If this is not the case, or data from study sites are not available, the transfer is not possible, and the method to be used is the CVM.

\section{The contingent valuation method}

CVM is well known, and was officially recommended as a technique for estimating non-marketable benefits of public goods conservation at the end of the 1970s in the USA, and in the 1990s in the UK (Polomé et al 2005). When the quantity of a resource is fixed, the CVM in the WTP version is the most suitable method for estimating conservation benefits by creating a hypothetical market by means of a questionnaire. Guidelines for applying the CVM have been established by Arrow et al (1993). We only note that, since individual WTP is measured by the amount of other goods a person is willing to give up for the benefits in question, an individual contribution can be asked in monetary terms or, when possible, in other forms such as specific works.

When WTP is directly asked in monetary terms, CVM needs the specification of a payment vehicle, such as a new tax and voluntary contribution (donation). The choice of the payment vehicle can determine responses biased towards underestimation or overestimation (Green and Tunstall, 1991). Therefore, its choice also depends on the specific situation considered. Extensive literature exists about which valuation question format yields the best estimates, but it is still an open issue. Much attention has been paid to the open-ended $(\mathrm{OE})$ and the dichotomous choice (DC) formats. Each has advantages and disadvantages, and the choice of one instead of the other depends on the specific situation peculiar to each case study. In particular, DC yields a less accurate estimate of the WTP than OE, since it only provides information on the upper and lower limits of the expected WTP and not on its maximum value; while 
OE permits the maximum mean WTP to be computed. In addition, although OE may lead to extreme responses, experience has shown that DC in general provides higher estimates than OE (Garrod et al, 1994).

\section{Aggregate WTP and the degree of certainty to pay}

If stakeholders state how much they are willing to pay for beach conservation, it is appropriate to compute the aggregate WTP. Therefore, we need to know the relevant population, which is the total number of stakeholders interested in its benefits. As regards visitors, this raises the issue of foreigners. When a site such as the Emilia-Romagna region is visited by foreigners, the extent of the market is not the national level (Marzetti, 2009) and the relevant population is identified with nationals and foreigners interested in beach quality.

The annual aggregate WTP $\left(W T P_{A}\right)$ is computed by multiplying the mean WTP $\left(W T P_{m}\right)$ by the relevant population $(N)$ :

$$
W T P_{A}=W T P_{m} N .
$$

Since the WTP is a hypothetical value, not all respondents may be certain to pay if actually asked. Although the National Oceanic and Atmospheric Administration Panel states that CV studies can produce reliable estimates (Arrow et al, 1993, p 8), it raises the problem that the CVM may overestimate the 'real' WTP and highlights studies where hypothetical values are found to be overestimated, sometimes by $50 \%$. This means that, to be conservative, $W T P_{A}$ must be weighted by a factor $\pi$ which represents the degree of certainty of actually paying (DCP). Therefore, we write:

$$
W W T P_{A}=W T P_{m} N \pi
$$

where $W W T P_{A}$ is the weighted aggregate WTP, and $\pi$ is measured on a scale from 0 to 1 ( 0 full uncertainty; 1 full certainty) and assumed to be equal for all individuals. In general, it seems reasonable to say that the more doubts there are about the 'reality' of the WTP, the lower the weighting factor. Goodman et al (1996) conclude that in some situations $\pi=0.1$ may be more appropriate than $\pi=0.5$. The value of $\pi$ may be also established according to the knowledge gained from studies that compare merely hypothetical WTPs with actual payments.

Furthermore, respondents willing to pay can be asked their DCP directly (on a scale from 0 to 100) by including a specific question in the questionnaire. Therefore the mean DCP $\left(\pi_{m}\right)$ can be computed and in Equation (2) it is $\pi=$ $\pi_{m}$. Marzetti (2012), for example, deals with an Italian case study where the weighting factor is found to be $\pi_{m}=0.88$. When the individual DCPs are known, the weighted aggregate WTP $\left(W W T P_{A}{ }^{\prime}\right)$ may be also computed according to Equation (3):

$$
W W T P_{A}{ }^{\prime}=\frac{\sum_{i=1}^{n} W T P_{i} \pi_{i}}{n} \cdot N,
$$

where $\mathrm{WTP}_{i}$ is the individual WTP, and $\pi_{i}$ is the individual DCP, $i=1, \ldots, n$ observations. In this computation those who are unwilling to pay have to be 
considered as $W T P_{i}=0$ and $\pi_{i}=0$; while those who do not answer the questions about the WTP or DCP should be excluded, therefore $n$ may be different from the total number of observations (whole sample).

\section{The design of the two CVM surveys}

No previous study was found on the evaluation of conservation benefits about beaches similar to those of Riccione and Misano Adriatico, and therefore the CVM was applied. The surveys were carried out from July to August 2007. Respondents were interviewed face-to-face $(15$ minutes) not only in the beach area under erosion but also in two beach areas (to the right and the left of the eroded area), where erosion is not yet present, since in the future these areas might be at risk of erosion. Anonymity was guaranteed. Interviews were undertaken by a market research firm. The questionnaire for beach visitors and that for sunbathing establishment managers were created in collaboration with the Assessorato Sicurezza Territoriale, Difesa del Suolo e della Costa, Protezione Civile of the Emilia-Romagna Regional Council. Interviewers were carefully trained.

Since, as regards visitors, data about DUV of a beach very similar to that of Riccione and Misano Adriatico were available at the time of the survey (Polomé et al, 2005; Marzetti, 2009), the Regional Council was interested in the estimate of their WTP in monetary terms for non-DUV. As regards sunbathing establishment managers, the Council was interested in knowing their WTP for beach conservation in monetary terms or beach works.

More specifically, as regards WTP in monetary terms, a donation to a nonprofit agency was considered suitable since, (a) in the case of visitors, beaches are also visited by foreign tourists who are non-tax payers in Italy, while, at the time of the surveys, a tourist tax was rejected because it was abolished in Italy in 1989 to boost the tourism sector, and (b) in the case of managers, an extra tax was rejected since they already pay a concession tax for beach use, and the income tax rate on Italian businesses is estimated to be higher than the mean European rate. As regards WTP in beach works, this kind of contribution is justified since managers are able to do them, and the Regional Council was aware that they might be unwilling to pay further in monetary terms.

As regards the visitor survey, a random sample of 606 beach visitors, aged over 18, was chosen according to monthly tourist arrivals (260 interviews in July and 346 in August) and time of day (morning and afternoon). It was stratified according to sex and place of origin (from the information provided by the local tourist office). Stratification according to age was not done since it is well known that in these sites the beach is mainly visited by young people. In addition, to avoid interviewing beach visitors of the same group, interviewees were chosen sequentially on the beach according to an interviewer's preestablished step: 1 beach visitor every 20 steps. The questionnaire was translated into English and French.

The survey of sunbathing establishment managers, instead, consisted of 120 face-to-face interviews, covering all the population of interest. Interviews were conducted at their establishments on the beach. 


\section{Beach visitors questionnaire}

In its final wording the questionnaire consisted of 10 sections from $\mathrm{A}$ to $\mathrm{J}$. In sections A-E respondents were asked about: (A) their residence, if they stayed at the site at least one night, their means of transport and their accommodation; (B) beach attendance and recreational activities, holiday cost per day at the site, and whether they visited the beach alone or in groups; (C) their perception of coastal erosion; (D) their beach quality rating, the reasons why they preferred to stay in the beach area where they were; (E) their attitude towards the preservation of natural resources.

Section $F$ included the elicitation questions. To obtain a more accurate estimate of the mean WTP and reduce the risk of hypothetical WTPs being higher than would be realistic, the OE format was chosen. First, the different beach economic benefits were briefly described. Respondents were also made aware that the beach is under erosion (Figure 2 is presented and described), and were asked their main reason for defending the beach and whether or not they were in favour of the implementation of the nourishment project. This was described to respondents by presenting Figure 3, in particular by specifying that it had a lower environmental impact and that the cost was about $€ 3.5$ million every five years. Since public funds may become scarce in future, respondents were asked (Shechter et al, 1998), (a) 'Would you be willing to make a voluntary donation to the cost of the project every 5 years, if you were sure that the public authority (non-profit organization) responsible for it would really spend the sum you donated on this project?' If the reply was 'yes', they were asked, (b) 'What is the highest amount you would be willing to pay every 5 years?'2

We point out that the WTP question was asked in terms of a lump sum and thus could not be split according to the different donation motives.

In section $\mathrm{G}$ donation and non-donation motives were solicited. In addition, given the hypothetical nature of this contingent market, those who were willing to pay were also asked on a scale from 1 to 100 how certain they were to pay (individual DCP), and the preferred means of donation. Those who were unwilling to pay were also asked if they were sure they were unwilling to pay.

Specific questions on ICZM perception and preferences about defence structures in general were included in section $\mathrm{H}$. Since a respondent's knowledge of ICZM is considered an individual characteristic, they were asked to state what ICZM meant in general. In addition, they were asked which of the options described in Figure 1 was their preferred structure.

In section I respondents' social characteristics were solicited, while in section J the interviewer was asked to state his or her judgement of the respondent's comprehension of the questionnaire.

\section{Sunbathing establishment managers questionnaire}

The questionnaire for sunbathing establishment managers was divided into seven sections. In sections A-D managers were asked about: (A) their residence, the type of services provided to beach visitors; (B) the characteristics of sunbathing establishments, the type and number of visitors; (C) their perception of coastal erosion, and their preferences concerning the different defence structures (Figure 1 was shown); (D) ICZM perception. 
Section (E) included the elicitation questions. Managers were asked if they were (a) willing to pay voluntarily for beach conservation (i) by a monetary donation to the public agency responsible for the implementation of the nourishment project every five years or (ii) by doing some beach maintenance work, such as beach cleaning and sand sieving, removal of winter dunes, maintenance of existing defence structures, and windbreak barriers - under the supervision of the same agency, the cost of which would be directly paid by the managers. In addition, (b) those who were willing to pay in monetary terms were also asked if they were willing to pay specifically for the implementation of the project and for some beach maintenance work (as specified above) done by the public agency - and their maximum donation. Those who were willing to do some beach work (as specified above) were also asked what type of work they were willing to do alone or in collaboration with other managers. Finally, motives behind contribution or non-contribution are solicited. Section F concerned respondents' social characteristics. In section $G$ the interviewer was asked to state his or her judgement of the respondent's comprehension of the questionnaire.

\section{How to enhance the reliability of the survey results}

To enhance the reliability of the results of the two CVM surveys, careful attention was paid to reducing and possibly avoiding: (a) no response and strategic behaviour, by presenting a realistic and credible scenario; and (b) methodological misspecification bias, by specifically training interviewers to prevent respondents unfamiliar with the valuation question actually answering a different question. In addition, (c) as regards information bias, the beach change was described through Figures 2 and 3, while (d) to avoid biases related to the questionnaire structure and wording, a pilot survey was carried out, and some modifications were made to the questionnaires. Finally, (e) on-site sampling bias (Gonzàlez-Sepùlveda and Loomis, 2010) seems not to be present, since all managers were interviewed and, as regards an over-representation of more frequent visitors in the sample, the correlation index of WTP and visitation frequency measured on beach days is 0.1594 and that measured in daily hours is 0.0289 .

\section{Donation models of private stakeholders}

In order to describe private stakeholders' behaviour when they are willing to donate for the conservation of a public good, such as a beach, we make reference to the general model by Andreoni (1989).

We model individual behaviour as follows. Let us assume that the total supply $Q$ of the beach is both publicly and privately provided, therefore $Q=$ $G+T$, where $G$ is individuals' total donation and $T$ is provided by the government. As regards $G$, let us indicate $G=g_{i}+G_{-i}$, where $g_{i}$, is the donation of individual $i$, and $G_{-i}=\Sigma_{j \neq i} g_{j}$ represents the donations of other individuals excluding $i$. Therefore, $Q=g_{i}+G_{-i}+T$. As regards $T$, let us assume that the national government funds the defence project with a share of taxes. Furthermore, let us assume that a rational individual, perfectly informed, maximizes 
utility, and that she or he may donate: (a) because she or he cares about the beach; and (b) since she or he gains enjoyment from donation per se (warm glow). The individual utility function is $U_{i}=U_{i}\left(\boldsymbol{w}_{i}, \boldsymbol{x}_{i}, Q, g_{i}\right)$, where $\boldsymbol{w}_{i}$ is a vector of $n$ individual characteristics, such as ICZM perception, attitudes and social characteristics, while $x_{i}$ is a vector of $m$ private goods. When warm glow is not present it is $U_{i}=U_{i}\left(w_{i}, x_{i}, Q\right)$, and the model is of pure altruism.

Since stakeholders considered here are beach visitors and sunbathing establishment managers who are in different conditions, we describe their behaviour through different models.

\section{Beach visitors' donation model}

Let us consider a visitor, $i=1, \ldots, r$. His or her budget constraint is $Y_{i}=x_{i}$ $+g_{i}+t_{i} Y_{i}$, where $Y_{i}$ is income, and $t_{i}$ is the domestic income tax. Let us write $T=\alpha t_{i} Y_{i}+T_{-i}$, where $\alpha$ is the share of income tax paid by individual $i$ devoted to the project by government, $0 \leq \alpha<1$, and $T_{-i}$ is the share of income taxes of all citizens excluding $i$ devoted to the project. Therefore, for a visitor $i$, it is:

$$
\begin{array}{ll}
\max & U_{i}\left(w_{i}, x_{i}, Q, g_{i}\right), \\
\text { s.t. } & Y_{i}=x_{i}+g_{i}+t_{i} Y_{i}, \\
& Q=g_{i}+G_{-i}+T, \\
& T=\alpha t_{i} Y_{i}+T_{-i} .
\end{array}
$$

Model (4) to (7) shows that a visitor pays for the public good provision through $g_{i}$ and $\alpha t_{i} Y_{i}$. The donation demand is:

$$
g_{i}^{*}=f_{i}\left[w_{i}, Y_{i}\left(1-t_{i}\right), G_{-i}+\alpha t_{i} Y_{i}+T_{-i}\right] .
$$

In Riccione and Misano Adriatico, beach visitors may be nationals or foreigners. As regards national visitors, Model (4) to (7) describes their rational behaviour. As regards foreign visitors, since foreign governments do not fund the defence project, Equation (7) cannot be considered in their behavioural model since they pay only through their donation (Marzetti and Disegna, 2012). Therefore, $T$ is exogenously determined and the demand function of a foreign visitor is:

$$
g_{i}^{*}=f_{i}\left[w_{\mathrm{i}}, Y_{i}\left(1-t_{i}\right), G_{-i}+T\right] .
$$

\section{Sunbathing establishment managers' donation model}

Managers are nationals and pay not only income tax but also an annual concession tax for beach use; that is, a lump sum $\operatorname{tax} l_{\mathrm{i}}, i=1, \ldots, v$. Therefore, assuming that $T=\alpha\left(t_{i} Y_{i}+l_{\mathrm{i}}\right)+T_{-i}$, the individual donation model is:

$$
\begin{array}{ll}
\max & U_{i}\left(w_{i}, x_{i}, Q, g_{i}\right), \\
\text { s.t. } & Y_{i}=x_{i}+g_{i}+t_{i} Y_{i}+l_{\mathrm{i}},
\end{array}
$$




$$
\begin{aligned}
& Q=g_{i}+G_{-i}+T, \\
& T=\alpha\left(t_{i} Y_{i}+l_{\mathrm{i}}\right)+T_{-i},
\end{aligned}
$$

and the managers' donation demand is:

$$
g_{i}^{*}=f_{i}\left[w_{i}, Y_{i}\left(1-t_{i}\right)-l_{\mathrm{i}}, G_{-i}+\alpha\left(t_{i} Y_{i}+l_{\mathrm{i}}\right)+T_{-i}\right] .
$$

As regards managers, the donation could be in monetary terms or in beach works, the cost of which is paid directly by them.

\section{Survey results about beach visitors}

The random sample of beach visitors consisted of $49.6 \%$ women and $50.4 \%$ men. The majority (59\%) were aged from 18 to 34, and the mean age was 34 . About $62 \%$ of respondents were single, $66 \%$ had attended school up to the age of 18 , and $17 \%$ had a university degree. Residents accounted for $13.5 \%$ and day-visitors for $24 \%$. The rest were tourists $(62.5 \%)$, the majority staying in hotels. As regards nationality, $90 \%$ of the respondents were Italians and the rest were foreign visitors, mainly from France, the UK and Switzerland.

As regards income, $91 \%$ of the respondents did not state the income category of their family. In Italy, experience shows that a non-negligible percentage of respondents (from about 35\% to 50\%) do not state family income (Marzetti, 2003, 2009; Marzetti and Disegna, 2012). However, in Riccione and Misano Adriatico this percentage was even higher, which may be due to the fact that the beach was visited by numerous (30\%) students, $96 \%$ of whom did not state their family income.

On a scale from 0 to 1 , the mean quality rating given to these beaches was 0.735 . Visitors visited the beach on average 17.89 days in spring/summer, and stayed on the beach on average 6 hours per day. Those who gave the highest quality ratings visited these beaches more often. The preferred recreational activities on the beach were sunbathing and swimming. The majority of respondents $(90 \%)$ visited the beach in groups, and $83 \%$ of these groups were without children. On average, visitors spent about $€ 55$ per day as holiday cost.

The great majority of respondents were aware of erosion problems, claimed that they were mainly loss of a natural environment (49\%) and loss of sand (40\%), thought that in general the cost of defence projects is justified (73\%), and were in favour of the implementation of the defence project from erosion $(87 \%)$. The main motives for defending these beaches were IUV (42\%), OV $(30 \%)$, and BV (16\%). A certain number of respondents (13\%) belonged to an association for the conservation of environmental goods.

\section{WTP and non-WTP: protest answers}

As regards WTP, visitors may be classified into three categories.

- Respondents who stated they were willing to pay but did not specify how much $(6.6 \%)$.

- Respondents who stated they were willing to pay and specified how much 


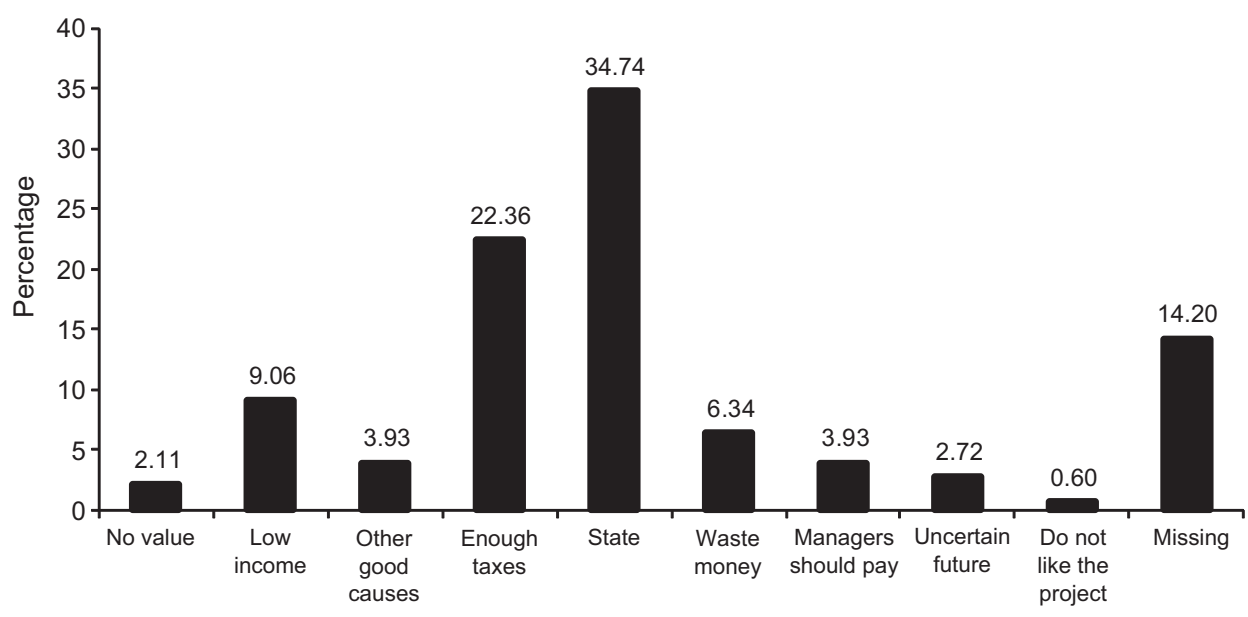

Figure 4. Beach visitors' non-donation motives (\% of respondents).

(38.6\%). They gave values from €1 to €9 (23.6\% from €1 to €4, and $15 \%$ from $€ 5$ to $€ 9)$.

- Respondents who were unwilling to pay and are considered as zero values in the mean computation (54.8\%).

Protest answers are identified by considering non-donation motives stated by those unwilling to pay. Among non-donation motives (see Figure 4), answers such as 'The state should pay' (34.7\%), 'I already pay enough taxes' (22.4\%), 'Non-profit agencies waste money' (6.3\%) and 'Sunbathing establishment managers should pay' $(3.9 \%)$ are considered as protest answers. This seems to suggest that these respondents $-67.3 \%$ of those unwilling to pay and $36.98 \%$ of the whole sample - do not agree with the ICZM recommendation that beach visitors should be involved in the conservation management of the beach by contributing in monetary terms.

Non-protest answers were: 'I have a low income' (9.1\% of non-donation motives), 'I prefer to donate to other good causes' (3.9\%), 'Uncertain future' $(2.7 \%)$, 'The project has no value for me' $(2.1 \%)$ and 'I do not like the project' $(0.6 \%)$.

\section{Beach visitors' observed mean WTPs}

Table 2 shows observed mean WTPs every five years computed after excluding those who stated that they are willing to pay but did not state how much: ${ }^{3}$

- whole sample, including zero values: €1.07 (median €0);

- sub-sample of those willing to pay: $€ 2.86$ (median $€ 2$ );

- sub-sample of those certain to pay: €2.83 (median €2).

Just over $65.93 \%$ of respondents to the question about WTP were certain to donate if actually asked, and $92.2 \%$ of them stated a DCP equal to or higher 
Table 2. Observed mean WTPs and mean DCP according to nationality.

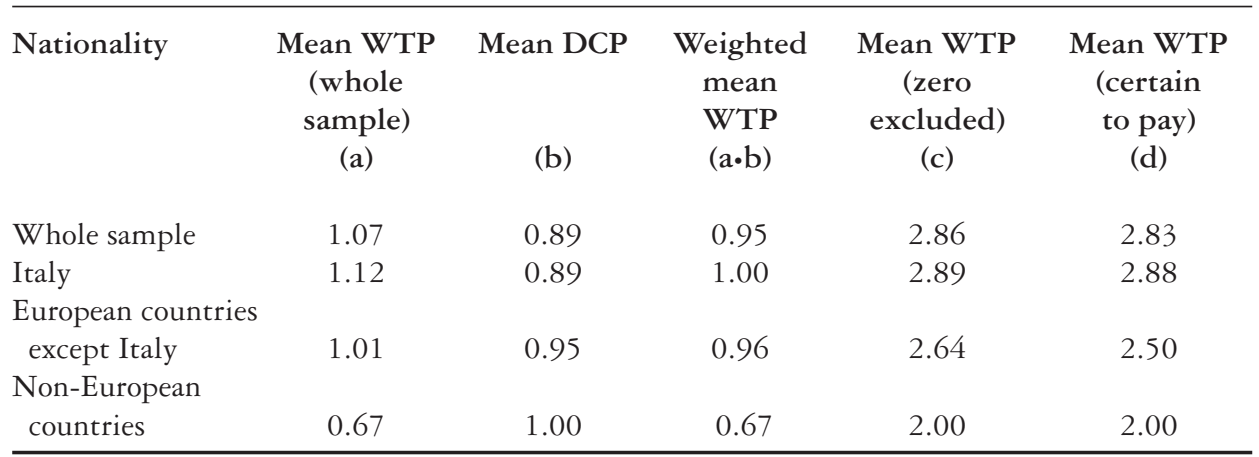

than $70 \%$. The mean DCP of these respondents is about $89 \%$, corresponding to a weighting factor $\pi_{m}=0.89$. Therefore for the whole sample, the weighted mean WTP is €0.95.

Distinguishing foreign visitors as non-Italian Europeans (8.82\%) and nonEuropeans $(1.18 \%)$, Table 2 shows that there is no great difference between the mean WTP of Italians and non-Italian Europeans, while the mean WTP is lower for non-Europeans. In addition, the mean DCP is higher for non-Italian Europeans and for non-Europeans than for Italians.

Finally, since the state of the beach has not changed significantly since 2007 (it continues to be eroded) and beach services are the same, it seems reasonable to update the mean value of the whole sample in order to compute visitors' aggregate WTP. Because non-Europeans are only $1.18 \%$ of the sample, we use the Consumer Price Index OECD Europe $114.127(2012 ; 2007=100)$ (http://stats.oecd.org, accessed 21 February 2013). Therefore the indexed (2012) weighted mean WTP, whole sample, is $€ 1.22$.

We highlight that the mean WTPs (whole sample) computed for this case study are lower than those estimated in the studies presented in Table 1; while the weighting factor is equal to that obtained for another Italian site (Marzetti and Disegna, 2012), and higher than those used for weighting the aggregate WTP for the British coast (Goodman et al, 1996).

\section{Visitors' donation motives}

Donation motives (first and second choices) are shown in Figure 5. The most important motive as first choice is OV, and as second choice is BV. These results seem to indicate that warm glow, intended as satisfaction from the mere act of donation, does not pertain to these stakeholders' preferences. In fact, in Figure 5 the item 'other' represents only one visitor who stated as second choice, 'I like the beach', and who cannot be classified as a respondent who draws satisfaction from the mere act of donation.

The majority of respondents willing to donate $(61 \%)$ thought that the amount donated should be deducted from income tax. As regards the most preferred means of donation, $31 \%$ would prefer to pay at a post office, $26 \%$ by text message, $16 \%$ by bank transfer or credit card, and $10 \%$ at the nonprofit agency responsible for the project implementation. 


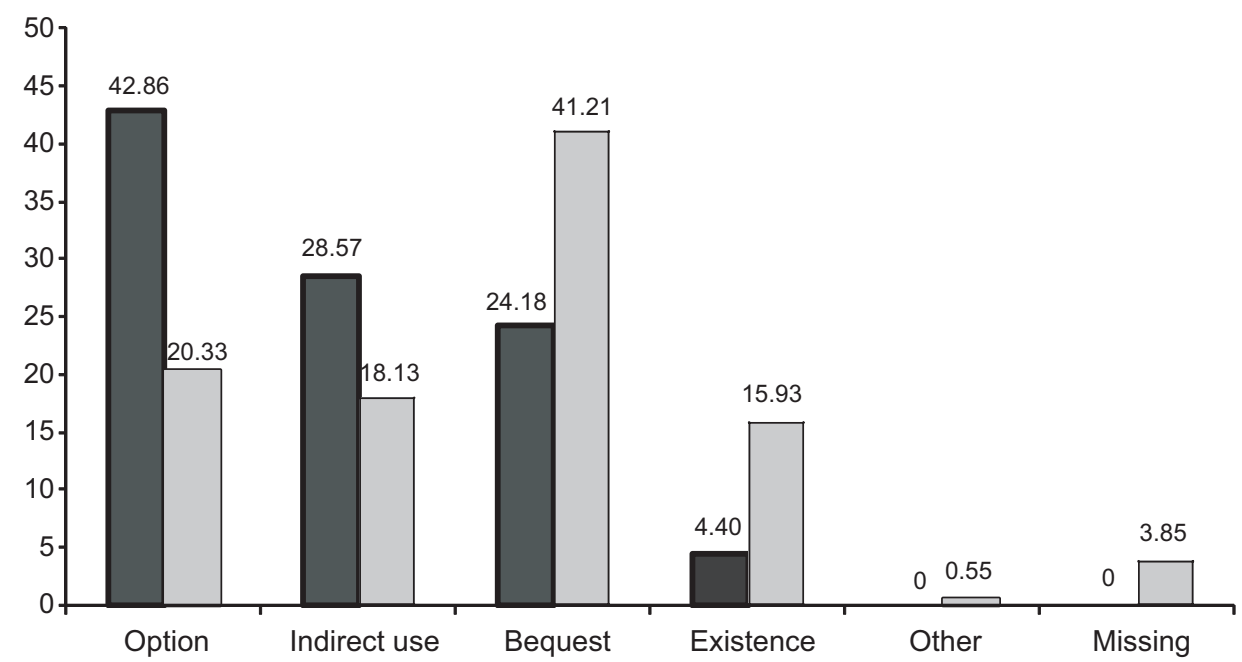

Figure 5. Beach visitors' WTP motives (\% of respondents).

\section{ICZM perception and preferences about defence structures}

The great majority of respondents were satisfied about the coastal management of the area by regional and local public authorities (72\%), and knew something about ICZM (61.22\%). More specifically, those who answered that ICZM is a 'sustainable coastal management considering social, economic and environmental aspects' are classified as those who know what ICZM is $(26.53 \%)$; those who answered that it is 'planning and managing coastal areas in order to preserve the quality of the water' or 'coastal management only as regards environment/ nature' are classified as partially knowing what ICZM is (34.69\%); those who answered that it is 'beach erosion monitoring and defence with artificial structures' are classified as not knowing what ICZM is (16.15\%); finally, $22.63 \%$ of respondents did not answer the ICZM question.

Table 3 shows that the highest percentages of those who gave a correct ICZM definition and a partially correct definition are among those who stated the highest WTPs; while, as regards those unwilling to donate (€0), the percentage of those who gave a correct definition is higher than that of the whole sample.

As regards defence structures, the most preferred was parallel submerged breakwaters $(26 \%)$, the second preferred was emerged breakwaters $(20 \%)$, and the third was nourishment (18\%); while $21 \%$ did not prefer any structures. We highlight that, though nourishment was the third preferred structure, only $0.6 \%$ of respondents stated as their non-donation motive that they did not like the (nourishment) project. The main motive of preference was the aesthetic impact $(48 \%)$, and the second was the belief that it is the most suitable for defending the beach from erosion (41\%). This result confirms that presented in Burcharth et al (2007) concerning Italian coastal sites. 


\begin{tabular}{lccccc}
\hline \multicolumn{5}{l}{ Table 3. WTP classes and ICZM perception. } \\
\hline \multicolumn{5}{l}{ ICZM perception (\%) } \\
WTP classes & Correct & Partially correct & Non-correct & Missing & Total \\
& & & & & \\
0 & 28.70 & 30.82 & 14.20 & 26.28 & 100 \\
1 & 27.71 & 39.76 & 15.66 & 16.87 & 100 \\
1.5 & 0 & 50.00 & 50.00 & 0 & 100 \\
2 & 20.00 & 30.00 & 15.00 & 35.00 & 100 \\
2.5 & 66.67 & 0 & 0 & 33.33 & 100 \\
3 & 57.14 & 42.86 & 0 & 0 & 100 \\
3.5 & 0 & 100 & 0 & 0 & 100 \\
4 & 66.67 & 0 & 0 & 33.33 & 100 \\
5 & 16.67 & 43.59 & 24.36 & 15.38 & 100 \\
6 & 0 & 100 & 0 & 0 & 100 \\
8 & 0 & 100 & 0 & 0 & 100 \\
9 & 0 & 100 & 0 & 0 & 100 \\
Whole sample & 26.53 & 34.69 & 16.14 & 22.63 & 100 \\
\hline
\end{tabular}

\section{Main determinants of beach visitors' WTP}

Since WTP values range from $€ 0$ to $€ 9$, and no respondents stated negative WTP, two regression models for beach visitors are considered: the two-stage model, estimated by adopting the Heien and Wessells (1990) approach, and the tobit model (Tobin, 1958). The best result is obtained through the two-stage model, which represents the donation process described in section $\mathrm{F}$ of the visitor questionnaire. This process consists of the decision on whether or not to donate (selection stage) and the decision on how much to donate (outcome stage), which are considered separately and admitting that different sets of variables and coefficients may determine them. The selection stage is estimated through a Probit model; the outcome stage through an OLS model (Heien and Wessells, 1990; Breen, 1996). This model is estimated (with STATA software) by using White's robust variance-covariance matrix to generate robust standard errors for our statistics (White, 1980). No observation is removed as outlier. ${ }^{4}$ Stepwise estimations are made for the significance level $\alpha=0.05$. Appendix A shows the complete list of independent variables.

The variable income requires some explanation. Given the high number of missing values (91\%), there is no one method more suitable than another to deal with them. We chose to create this variable: (a) by considering the mean of each income category for those who specify income; and (b) by using propensity score matching (PSM) (Rosembaum and Rubin, 1983; Sisto, 2006) for missing Italians income data (67.16\% of the whole sample). The PSM method allows each observation to be associated - in terms of sociodemographic and economic features - with the most similar observation of another survey which contains the information on income missing in the former. A measure of distance, usually the Euclidean one, is used to evaluate the similarity between units. Through PSM we reconstruct approximately the missing incomes for Italian visitors by using the database from a 2006 national survey carried out by the Central Bank of Italy. The variables used for the 
Table 4. Determinants of beach visitors' probability of paying and WTP.

\begin{tabular}{lcc}
\hline Independent variables & $\begin{array}{c}\text { Two-stage model } \\
\text { Probit }^{\mathrm{a}}\end{array}$ & OLS $^{\mathrm{b}}$ \\
Missing income (Italians) & & $-0.542(0.24)$ \\
Being informed about ICZM & $0.361(0.17)$ & \\
Satisfied with regional coastal management & $1.022(0.16)$ & \\
In favour of the project & $0.707(0.23)$ & \\
SMPAND & $-0.475(0.13)$ & $-0.479(0.18)$ \\
Option value & $-0.384(0.13)$ & $-0.432(0.15)$ \\
Medium quality rating & & \\
Single & $0.266(0.13)$ & $0.354(0.16)$ \\
Secondary education & & $-0.45(0.16)$ \\
Walking/sports & $0.625(0.15)$ & $-0.497(0.22)$ \\
Aged 28-49 & & $0.466(0.20)$ \\
Aged 49-65 & & $0.730(0.19)$ \\
Centre of Italy & & $1.307(0.21)$ \\
North-East of Italy & & $0.791(0.31)$ \\
MR & $-1.730(0.29)$ & \\
Constant & & \\
\hline
\end{tabular}

Notes: Robust standard errors are in parentheses. ${ }^{a}$ Number of observations $=479$; Wald chi2 $(7)=$ 76.81; Prob > chi2 $=0$; McKelvey-Zavoina $R^{2}=0.320$; Log likelihood $=-265.61562 .{ }^{\text {b }}$ Number of observations $=479 ; F(9,469)=11.47 ;$ Prob $>F=0 ;$ Adjusted $R^{2}=0.164$.

matching procedure are: profession, gender, age, education and civil status (Banca d'Italia, 2006). The use of the PSM procedure is preferable to that of using a single variable (such as education or occupation) as proxy for income in order to avoid a further bias in the estimate. In addition, two dummies are created: missing income (Italians) and missing income (foreigners) for Italians and foreigners, respectively, who did not state income. Finally, the $D C P$ variable is excluded from the Probit, since it creates an estimate problem, but it is included in the OLS stage.

Table 4 shows the regression results. The MR coefficient ${ }^{5}$ is significant; therefore, for beach visitors, the decisions to donate voluntarily and how much to donate are dependent, but these decisions are explained by different sets of variables and coefficients. According to economic theory, income is generally the main independent variable affecting WTP. Nevertheless, in this model only the coefficient of the variable missing income (Italians) is significant and negative, and this shows that the WTP is lower for those Italians who did not state income.

Other variables affect the probability of paying and the WTP. Both probability of paying and WTP decrease if respondents stated that society should spend more for the populations affected by natural disasters (SMPAND). As regards the probability of paying, this increases if respondents were informed about what ICZM is, were in favour of the project, were satisfied with the regional coastal management, were single, and if their main beach recreational activities were walking and sports; while it decreases if their motive of donation was option value though it is the main donation motive. WTP decreases if respondents ascribed to the beach a medium quality rating, and if they were aged 28-65; and 
it increases if respondents had secondary education and came from the NorthEast and the centre of Italy. The expected mean WTP is $€ 1.08$ (median €0).

\section{Visitors' aggregate values for beach conservation}

The aggregate WTP of visitors is computed to ascertain, in a case of scarcity of public funds, how much the regional policymaker could collect every five years through a visitors' donation campaign. In this computation, to be conservative, we use the observed mean WTP €1.07, since it is lower than the expected mean value $€ 1.08$ computed through the two-stage model.

According to Equation (2), by considering $N=1$ million visitors, $W T P_{m}=$ $€ 1.07$ (indexed value $2012, € 1.22$ ) and $\pi_{m}=0.89$ (mean DCP), the weighted total donation of beach visitors $\left(W W T P_{A}\right)$ for the project is estimated to be about $€ 952,000$ (indexed value 2012 about $€ 1,090,000$ ). According to Equation (3), $W W T P_{A}{ }^{\prime}$ is about $€ 999,000$ (indexed value 2012 about $€ 1,140,000$ ). Therefore, given these values, the total donation of beach visitors may cover from one quarter to about one third of the implementation cost of the defence project.

\section{Survey results for sunbathing establishment managers}

The majority (87.5\%) of managers are residents in Riccione and Misano Adriatico. As regards education, $47.5 \%$ of them only have compulsory schooling (up to the age of 13), $46 \%$ secondary education (up to the age of 18) and the rest a university degree. About $11 \%$ of managers would use a larger beach area for their business, mainly for improving the quality of the services provided and due to the increased number of customers. No one stated their household income.

\section{Managers' awareness about ICZM}

The great majority of these managers (80\%) knew something about ICZM. In particular, $37 \%$ gave a correct definition and $43 \%$ a partially correct definition; while $18 \%$ did not know what ICZM is, and $2 \%$ did not answer. The majority of respondents were satisfied with the coastal management of the area by regional and local policymakers, were aware of erosion problems, familiar with defence structures, and in favour of the defence project (82.5\%), though their preferred structure was parallel submerged breakwaters (60\%) while nourishment was the second preference (20.8\%). In addition, the majority believed that the cost for defending the beach from erosion was justified.

$$
\text { WTP for beach defence }
$$

As regards managers' WTP for beach defence, $63.33 \%$ were unwilling to pay in monetary terms or in beach works. Among those willing to pay:

- $9 \%$ stated in monetary terms, but none specified the maximum donation; instead, they specified the number and kind of maintenance works they were willing to pay for; 
Table 5. Beach work distribution by managers.

\begin{tabular}{lrr}
\hline Number of works & Number of Managers & $\%$ \\
0 & 76 & 63.33 \\
1 & 9 & 7.50 \\
2 & 25 & 20.83 \\
3 & 3 & 2.50 \\
4 & 2 & 1.67 \\
5 & 4 & 3.33 \\
6 & 1 & 0.83 \\
Total & 120 & 100.00 \\
\hline
\end{tabular}

- $27.5 \%$ stated they were willing to do some maintenance work to the beach or defence structures, thus showing they were able to manage these works directly. Table 5 shows the beach work distribution.

As regards maintenance works to be done by a single manager, the vast majority of managers $(84.85 \%)$ were willing to do beach cleaning and sand sieving, and the rest were willing to remove winter dunes. Of those who were willing to do more than one maintenance task in collaboration with other managers, Figure 6 shows that the majority stated that they were willing to remove winter dunes $(54.55 \%)$.

\section{Donation and non-donation motives}

As regards donation motives, as first choice, the importance of the beach for the managers' own business $(65.8 \%)$ stands out; while as second choice it is IUV $(61.7 \%)$. For those unwilling to pay, the main non-donation motives were that they thought 'beach defence is a state duty' (66\%), and that they were already paying the concession tax (30\%). This suggests that, like beach visitors,

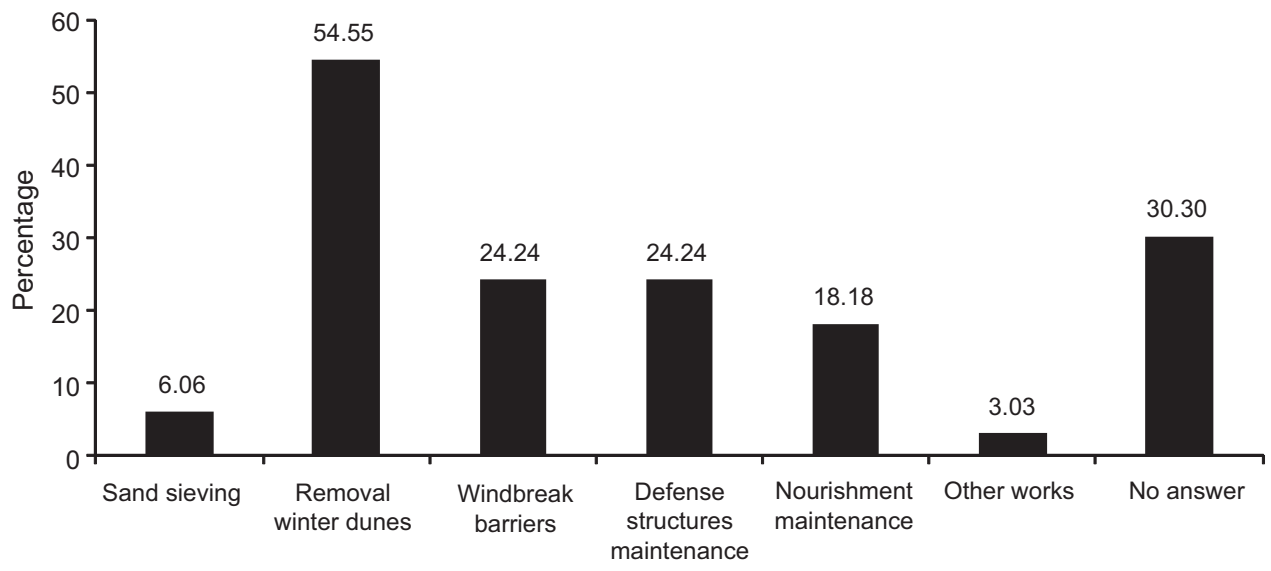

Figure 6. Maintenance works to be done in collaboration with other managers (\% of respondents). 


\begin{tabular}{|c|c|c|}
\hline \multirow[b]{2}{*}{ Independent variables } & \multicolumn{2}{|c|}{ Two-stage model } \\
\hline & Probit $^{\mathrm{a}}$ & $\mathrm{ZTP}^{\mathrm{b}}$ \\
\hline ICZM & $0.555(0.25)$ & \\
\hline In favour of the project & $1.038(0.36)$ & \\
\hline Loss of sand and environment deterioration & & $0.495(0.22)^{\mathrm{a}}$ \\
\hline Coastal zone is beach, sea and hinterland & & $0.742(0.23)$ \\
\hline Satisfied with regional coastal management & & $-0.588(0.23)$ \\
\hline Constant & $-1.448(0.35)$ & $0.647(0.16)$ \\
\hline
\end{tabular}

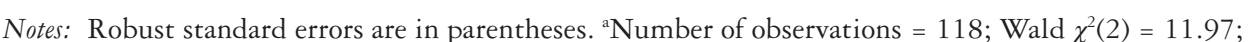
Prob $>\chi^{2}=0$; McKelvey-Zavoina $R^{2}=0.160 ;$ Log likelihood $=-72.01257 .{ }^{\mathrm{b}}$ Number of observations $=44$; Wald $\chi^{2}(3)=13.26$; Prob $>\chi^{2}=0$; Pseudo $R^{2}=0.101$

the majority of managers $(60.48 \%$ of the whole sample) do not agree with the ICZM recommendation that they, as stakeholders, should pay for beach defence in monetary terms or by doing maintenance work.

\section{Main determinants of managers' WTP}

Ideally, according to Model (10) to (14), we should measure beach non-DUV by WTP. Nevertheless, the manager survey provides data on the number of maintenance works, since even those willing to donate in monetary terms do not specify their maximum WTP but only the number of beach works for which they are willing to pay. Therefore, since it is reasonable to think that those willing to contribute through more works are willing to pay more than those willing to contribute through fewer works (see Table 5), we model their behaviour by using a hurdle count model. This represents a two-stage decisionmaking process, which admits that the model governing the zeros 'might differ from that determining the magnitude of the positive counts' (Mullahy, 1986, p 342; Cameron and Trivedi, 1998, p 124). A Probit is estimated for the first stage, which predicts whether a manager will be a donor or non-donor, and a zero-truncated Poisson for the second stage, which predicts the probability of donating for one or more beach works. Estimations are made for the significance level $\alpha=0.05$. The complete list of variables is presented in Appendix B. Income is not included as independent variable, since it was not stated by any respondent, and the PSM procedure for missing incomes is not applied because the managers belong to the same professional category.

Table 6 shows that, as regards the first stage, the probability of donating increases if managers know what ICZM is, and are in favour of the defence project. As regards the second stage, if managers are not aware that the main erosion consequence is loss of sand and environment deterioration and that a coastal zone is beach, sea and binterland the average number of beach works is 1.9, while if they are aware, the average number is 6.6 (that is, $\exp (0.647+0.495+$ $0.742)$ ), keeping the other explanatory variables constant. In addition, if managers are not satisfied with regional coastal management the estimated average number of beach works for which they are willing to pay, or are willing to do, is $1.9(\exp (0.647))$, while if they are satisfied with regional coastal management 
the average number of beach works decreases to $1.1(\exp (0.647-0.588))$, keeping the other explanatory variables constant. This last result seems to highlight that the more the policymaker implements good projects against erosion, the less managers believe it is necessary to contribute to coastal management in beach works.

\section{Conclusion}

This research shows that the majority of private stakeholders are satisfied with the coastal management of Riccione and Misano Adriatico beaches by regional and local policymakers, are fully or partially aware of what ICZM is, and believe that the cost of defence projects is justified. The great majority are in favour of the implementation of the nourishment project, although, of the different defence structures, nourishment is the third preference for visitors, while it is the second for managers. This seems to suggest that on these sites the conservation of the beach in itself is more important than how it is conserved.

The majority of both visitors and managers are unwilling to pay for beach conservation. Since the main justifications are that the state should pay for defence projects, and that they already pay enough taxes, this suggests that a non-negligible number of stakeholders may not agree with the ICZM recommendation that they should be involved in beach management by directly contributing in monetary terms or through maintenance works, and believe that public funds should be used.

Nevertheless, the number of those who are willing to pay is also nonnegligible. As regards beach visitors (whole sample), the mean WTP weighted by the mean DCP is about $€ 1$ and this is in line with some real donation campaigns for collecting funds for other good causes where $€ 1$ is suggested as a minimum amount of donation. Distinguishing visitors according to nationality, non-Italian Europeans and non-Europeans are willing to donate less than Italians but their degree of certainty to donate is higher than that of Italians. As regards managers, those who are willing to contribute would mainly prefer to pay a public agency in monetary terms for some beach maintenance work than for the implementation of the project, or to do some works directly since they are able to manage them.

The main visitors' donation motive (first choice) is to have the option to visit the beach in the future, and for managers it is the importance of the beach for their own business. As second choice, the awareness that the beach should be conserved for future generations (BV) prevails over other donation motives for visitors, while IDV prevails for managers. Since values such as visitors' concern for future generations and managers' concern for storm protection and flood control are part of stakeholders' moral obligations other than the benefits provided by personal future beach use, this seems to show stakeholders' awareness that beaches should be managed according to the dictates of sustainability and, more specifically, of ICZM.

As regards regression analysis, we stress that the surveys do not provide data about income, since $91 \%$ of visitors and all managers did not state it. This shows that income is a variable to which a respondent is very sensitive. Therefore, we are unable to estimate the influence of this important economic 
variable on stakeholders' behaviour about the defence project by using respondents' data. Nevertheless, as regards visitors, having the possibility to transfer the data of another survey which contains the information on missing income to our analysis, we find that income does not affect their probability of paying and WTP. Non-economic variables affect stakeholders' behaviour.

Comparing regression results, the probability of donating for beach defence in monetary terms on the part of visitors and also with beach works on the part of managers increases if these stakeholders are in favour of the implementation of the project and if they are informed about ICZM. This suggests that policymakers have to pay special attention to private stakeholders' information about the integrated management of the coast if they want to increase the probability of contributing voluntarily to the implementation of conservation projects. Therefore, promoting an information and education campaign about the benefits from an integrated management of the coast may be important in order to increase stakeholders' probability of paying. Finally, as regards visitors, the probability of donating also increases if they are satisfied with the regional coastal management, while for managers the probability of paying for, or being willing to do, a higher number of beach works is lower if they are satisfied with regional coastal management. This seems to show that, the more the policymakers manage the coast to satisfy stakeholders' needs, the more visitors are stimulated to contribute, while managers believe that their contribution in beach works can be reduced.

\section{Endnotes}

1. For a description of the different kinds of defence structures see Burcharth et al (2007).

2. We highlight that a payment card was not taken into consideration since the resulting dependent variable is not continuous and is subject to 'range bias'.

3. Since only $10.4 \%$ of respondents did not answer the valuation question, in order to avoid further bias in the estimate we have decided to exclude them instead of substituting an average (such as the mean and the median) for the missing values.

4. Outliers are observations that take values implausibly low or high, referring to the rest of the data, given some influential determinant of the WTP. Since $90 \%$ of respondents do not state their income, an OLS regression is estimated by considering the travel cost as independent variable, but it was found to be non-significant.

5. MR is included as independent variable in the OLS model for incorporating the censoring latent variable in the second stage. Its coefficient is an estimate of the ratio between the covariance of error terms of the equations about the two stages and the standard deviation about the first stage error. If this coefficient is zero, the decision to pay and that of how much to pay are independent (Heien and Wessells, 1990).

\section{References}

Akyarh, A., Uslu, O., Saner, E., and Üçüncüoðlu (1997), 'An integrated approach for natural resource management in the Izmir Bay', in Ozhan, E., ed, Proceedings of the Third International Conference on the Mediterranean Coastal Environment, MEDCOAST 97, Qawra, Malta, pp 547-561.

Andreoni, J. (1989), 'Giving with impure altruism: application to charity and Ricardian equivalence', The Journal of Political Economy, Vol 97, No 6, pp 1447-1458.

Arrow, K., Solow, R., Portney, P.R., Learner, E.E., Radner, R., and Shuman, H. (1993), 'Report of the NOAA panel on contingent valuation. Report to the general counsel of the US National Oceanic and Atmospheric Administration. US Department of Commerce. Natural resource damage assessments under the Oil Pollution Act of 1990', Federal Register. Vol 58, No 10, pp 46014614.

Banca d'Italia (2006), 'I bilanci delle famiglie italiane nel 2006' (http://www.bancaditalia.it/statistiche/ indcamp/bilfait, accessed 11 June 2012). 
Breen, R. (1996), Regression Models. Censored, Sample-Selected, or Truncated Data, SAGE Publications, London.

Burcharth, H., Hawkins, S.J., Zanuttigh, B., and Lamberti, A. (2007), Environmental Design Guidelines for Low Crested Coastal Structures, Elsevier, Amsterdam.

Cameron, A.C., and Trivedi, P.K. (1998), Regression Analysis of Count Data, Cambridge University Press, Cambridge.

Council of Europe (1997), Of the Committee of Ministers to the Member States on a Policy for the Development of Sustainable Environment-friendly Tourism in Coastal Areas, Recommendation No R(97) 9.

European Union (EU) (2009), Protocol on integrated coastal zone management in the Mediterranean', Official Journal of European Union, L34/19-L34/28.

Garrod, G.D., Willis, K.G., and Saunders, C.M. (1994), 'The benefits and costs of the Somerset Levels and Moors ESA', Journal of Rural Studies, Vol 10, No 2, pp 131-145.

Gonzàlez-Sepùlveda, J.M., and Loomis, J.B. (2010), 'Do CVM welfare estimates suffer from on-site sampling bias? A comparison of on-site and household visitor surveys', Agricultural and Resource Economics Review, Vol 39, No 3, pp 561-570.

Goodman, S.L., Seabrooke, W., Daniel, H.M., Jaffry, S.A., and James, H. (1996), Results of a Contingent Valuation Study of Non-use Values for Coastal Resources. Research Report to MAFF Flood and Coastal Defence Division, Centre for Coastal Zone Management, University of Portsmouth, Portsmouth

Green, C.H., and Tunstall, S.M. (1991), 'The evaluation of river quality improvements by the contingent valuation method', Applied Economics, Vol 23, pp 1135-1146.

Heien, D., and Wessells, C. (1990), 'Demand system estimation with micro data: a censored regression approach', Journal of Business and Economic Statistics, Vol 8, No 3, pp 356-371.

Huber, R.M., and Jameson, S.J. (2000), 'Integrated coastal zone management in the tropical Americas and the role of decision support models', in Gustavson, K., Huber, R.M., and Ruitenbeek, J., eds, Integrated Coastal Zone Management of Coral Reefs: Decision Support Modelling, The World Bank, Washington, DC, pp 3-21.

Ioppolo, G., Saija, G., and Salomone, R. (2013), 'From coastal management to environmental management: the sustainable eco-tourism program for the mid-western coast of Sardinia', Land Use Policy, Vol 31, pp 460-471.

King, O.H. (1995). 'Estimating the value of marine resources: a marine recreation case', Ocean $\mathcal{E}$ Coastal Management, Vol 27, pp 29-141.

Koutrakis, E.T., Sapounidis, A., Marzetti, S., Marin, V., Roussel, S., Martino, S., Fabiano, M., Paoli, C., Rey-Valette, H., Povh, D., and Malvárez, C.G. (2011), 'ICZM and coastal defence perception by beach users: lessons from the mediterranean coastal area', Ocean and Coastal Management, Vol 54, pp 821-830.

Marzetti, S. (2003), 'Economic valuation of the recreational beach use: the Italian case studies of Lido di Dante, Trieste, Ostia and Pellestrina island', D28/A, in Economic and Social Valuation about European Coastal Sites, D28, pp. 1-73, research project DELOS (Environmental Design of Low Crested Coastal Defence Structures), EU Fifth framework programme 1998-2002, Energy, Environment and Sustainable Development (http://www.delos.unibo.it/).

Marzetti Dall'Aste Brandolini, S. (2009), 'Recreational demand functions for different categories of beach visitor', Tourism Economics, Vol 15, No 2, pp 339-365.

Marzetti Dall'Aste Brandolini, S., and Disegna, M. (2012), 'Demand for quality conservation of Venice (Italy) according to different nationalities', Tourism Economics, Vol 18, No 5, pp 1019-1050.

Mullahy, J. (1986), 'Specification and testing of some modified count data models', Journal of Econometrics, Vol 33, pp 341-365.

Nasr, S.M., El-Raey, M., and Ahmed, M.H. (1997), 'Integrated coastal zone management in Alexandria, Egypt', in Ozhan, E., ed, Proceedings of the Third International Conference on the Mediterranean Coastal Environment, MEDCOAST 97, Qawra, Malta, pp 563-577.

Polomé, P., Marzetti, S., and van der Veen, A. (2005), 'Economic and social demands for coastal protection', Coastal Engineering, Vol 52, No 10/11, pp 819-840.

Regione Emilia-Romagna (2006), Ordinanza Balneare, n. 1/2006 (http://www.regione.emiliaromagna.it.)

Rosembaum, P., and Rubin, D.B. (1983), 'The central role of the propensity score in observational studies for casual effects', Biometrika, Vol 70, pp 41-50.

Rupprecht Consult-Forthung Beratung GmbH and International Ocean Institute (2006), 'Evaluation of integrated coastal zone management (ICZM) in Europe', final report, Rupprecht Consult, Cologne. 
Shechter, M., Reiser, B., and Zaitsev, N. (1998), 'Measuring passive use value', Environmental and Resources Economics, Vol 12, pp 457-478.

Silberman, J., and Klock, M. (1988), 'The recreation benefits of beach renourishment', Ocean and Shoreline Management, Vol 11, pp 73-90.

Silberman, J., Gerlowski, D.A., and Williams, N.A. (1992), 'Estimating existence value for users and nonusers of New Jersey beaches', Land Economics, Vol 68, No 2, pp 225-236.

Sisto, A. (2006), 'Propensity score matching: un'applicazione per la creazione di un database integrato ISTAT-Banca d'Italia', POLIS working papers, Institute of Public Policy and Public Choice - POLIS (http://EconPapers.repec.org/RePEc:uca:ucapdv:56, accessed 15 May 2015).

Sorensen, J. (2002), 'The status of integrated coastal management as an international practice', Baseline 2000 background report, Second Iteration, Urban Harbors Institute Publications, Boston, paper 31.

Spash, C.L., van der Werff ten Bosh, J., Westmacott, S., and Ruitenbeek, J. (2000), 'Lexicographic preferences and the contingent valuation of coral reef biodiversity in Curacao and Jamaica', in Gustavson, K., Huber, R.M., and Ruitenbeek, J., eds, Integrated Coastal Zone Management of Coral Reefs: Decision Support Modelling, The World Bank, Washington, DC, pp 97-117.

Subade, R.F. (2005), 'Valuing biodiversity conservation in a world heritage site: citizens' non-use values for Tubbataha Reefs National Marine Park, Philippines', research report EEPSEA (Economy and Environment Program for South Asia), EEPSEA, Singapore.

Tobin, J. (1958), 'Estimation of relationships for limited dependent variables', Econometrica, Vol 26, pp 24-36.

Turner, R.K. (1999), 'The place of economic values in environmental valuation', in Bateman, I.J., and Willis, K.G., eds, Valuing Environmental Preferences, Oxford University Press, Oxford, pp 1741.

White, H. (1980), 'A heteroscedasticity-consistent covariance matrix estimator and a direct test for heteroscedasticity', Econometrica, Vol 48, pp 817-838.

World Bank (1996), 'Guidelines for integrated coastal zone management', Environmentally Sustainable Development Studies and Monographs Series 9, World Bank, Washington, DC. 


\section{Appendix A}

Beach visitors - list of independent variables

Independent

Definition

Percentage

variable

(obs 479)

Days

Walking/sports

Number of daily beach visits per year (continuous variable)

Swimming

1 = Walking or sports as main recreational activity;

Sunbathing

$0=$ otherwise

26.72

$1=$ Swimming as main recreational activity; $0=$ otherwise

18.58

Playing/others

$1=$ Sunbathing as main recreational activity; $0=$ otherwise

52.82

$1=$ Playing or other beach activities as main recreational activity; 0 = otherwise (reference category)

Erosion consequences

1 = Noticing some consequences of coastal erosion;

$0=$ otherwise

Justified cost of beach

$1=$ Believing that the cost of beach defence projects is

defence justified; $0=$ otherwise

73.90

High quality rating

$1=$ Beach quality rating from 8 to $10 ; 0=$ otherwise

48.64

Medium quality rating

Low quality rating

$=$ Beach quality rating from 4 to $7 ; 0=$ otherwise

49.69

$1=$ Beach quality rating equal from 1 to $3 ; 0=$ otherwise (reference category)

Being informed about

1 = Being informed about what ICZM is; 0 = otherwise

what ICZM is

SMPAND

1 = Spending more for people in areas affected by natural disasters; $0=$ otherwise

SEPAND

1 = Spending equal for people in areas affected by natural disasters; $0=$ otherwise

SLPAND $\quad 1$ = Spending less for people in areas affected by natural disasters; 0 = otherwise (reference category)

$S M E C$

$1=$ Spending more for environmental conservation;

$0=$ otherwise

SEEC

$1=$ Spending equal for environmental conservation;

$0=$ otherwise

SLEC

1 = Spending less for environmental conservation;

$0=$ otherwise (reference category)

Option value

$1=$ Option is the main motive (first choice) for defending the beach from erosion; $0=$ otherwise

Existence value

$1=$ Existence value is the main motive (first choice) for defending the beach from erosion; $0=$ otherwise

Other motives

$1=$ Indirect use value or other motives are the main motives (first choice) for defending the beach from erosion;

$0=$ otherwise (reference category)

In favour of the project 1 = Being in favour of the beach defence project;

$0=$ otherwise

Satisfied with regional

$1=$ Being satis

coastal management management; $0=$ otherwise

Single $\quad 1$ = Being single (unmarried); 0 = otherwise

Schooling up to 13 years 1 = Having had schooling up to the age of 13 only;

$0=$ otherwise (reference category)

Schooling up to 18 years $1=$ Having had schooling up to the age of $18 ; 0=$ otherwise 
Beach visitors - list of independent variables

\begin{tabular}{|c|c|c|}
\hline $\begin{array}{l}\text { Independent } \\
\text { variable }\end{array}$ & Definition & $\begin{array}{l}\text { Percentage } \\
\text { (obs 479) }\end{array}$ \\
\hline University degree & $1=$ Having a university degree $0=$ otherwise & 15.45 \\
\hline Manager/self-employed & $1=$ Being manager $/$ self-employed; $0=$ otherwise & 17.75 \\
\hline Office worker & $1=$ Being an office worker; $0=$ otherwise & 44.47 \\
\hline Student & $1=$ Being a student $; 0=$ otherwise & 31.10 \\
\hline$T L H P U$ & $\begin{array}{l}1=\text { Being a teacher/labourer/housewife/Pensioner/ } \\
\text { unemployed; } 0=\text { otherwise (reference category) }\end{array}$ & 6.68 \\
\hline Sex & 1 = Being male; $0=$ otherwise & 52.61 \\
\hline Aged 18-28 & $\begin{array}{l}1=\text { from } 18 \text { to } 28 \text { years old } ; 0=\text { otherwise } \\
\text { (reference category) }\end{array}$ & 44.47 \\
\hline Aged 29-49 & $1=$ from 29 to 49 years old $0=$ otherwise & 42.80 \\
\hline Aged 50 and over & $1=50$ years old and over; $0=$ otherwise & 12.73 \\
\hline Centre of Italy & $1=$ Living in the Centre of Italy; $0=$ otherwise & 19.83 \\
\hline North-East of Italy & $1=$ Living in the North-East of Italy; $0=$ otherwise & 50.31 \\
\hline North-West of Italy & 1 = Living in the North-West of Italy; $0=$ otherwise & 16.08 \\
\hline \multirow[t]{2}{*}{ South/Islands of Italy } & 1 = Living in the South or in the Islands of Italy; & \\
\hline & $0=$ otherwise & 3.55 \\
\hline Abroad & $1=$ Not living in Italy $0=$ otherwise (reference category) & 10.23 \\
\hline Income & $\begin{array}{l}\text { The mid-point of each income category is used (when income } \\
\text { is not stated it is estimated through PSM); } 0 \text { = respondents } \\
\text { do not state their income category (continuous variable) }\end{array}$ & - \\
\hline Missing income & $1=$ Foreign respondent does not state income category; & \\
\hline (foreigners) & $0=$ otherwise & 8.98 \\
\hline Missing income & 1 = Italian respondent does not state income category; & \\
\hline (Italians) & $0=$ otherwise & 83.30 \\
\hline MR & Inverse Mill's Ratio & \\
\hline
\end{tabular}




\section{Appendix B}

\begin{tabular}{|c|c|c|}
\hline \multicolumn{3}{|c|}{ Sunbathing establishment managers - list of independent variables } \\
\hline $\begin{array}{l}\text { Independent } \\
\text { variable }\end{array}$ & Definition & $\begin{array}{l}\text { Percentage } \\
\text { (obs 479) }\end{array}$ \\
\hline Enough beach area & $\begin{array}{l}1=\text { The beach area used by managers for their business is } \\
\text { large enough; } 0=\text { otherwise }\end{array}$ & 88.79 \\
\hline $\begin{array}{l}\text { Erosion: loss of sand } \\
\text { and environment } \\
\text { deterioration }\end{array}$ & $\begin{array}{l}1=\text { Believing that beach erosion is loss of sand and } \\
\text { environment deterioration; } 0=\text { otherwise }\end{array}$ & 35.51 \\
\hline $\begin{array}{l}\text { Parallel emerged } \\
\text { breakwater }\end{array}$ & $1=$ Preferring parallel emerged breakwater; $0=$ otherwise & 10.28 \\
\hline $\begin{array}{l}\text { Parallel submerged } \\
\text { breakwater }\end{array}$ & $1=$ Preferring parallel submerged breakwater; $0=$ otherwise & 61.68 \\
\hline Pure nourishment & $1=$ Preferring pure nourishment; $0=$ otherwise & 19.63 \\
\hline Other protection & $\begin{array}{l}1 \text { = Preferring other protections to parallel emerged } \\
\text { breakwater, parallel submerged breakwater, pure nourishment } \\
\text { or no protection; } 0=\text { otherwise }\end{array}$ & 8.41 \\
\hline Justified cost & $\begin{array}{l}1=\text { Believing that the cost of the project is justified; } \\
0=\text { otherwise }\end{array}$ & 79.44 \\
\hline $\begin{array}{l}\text { Coastal zone is beach, } \\
\text { sea and binterland } \\
\text { ICZM }\end{array}$ & $\begin{array}{l}1=\text { Believing that a coastal zone is beach, sea and hinterland; } \\
0=\text { otherwise } \\
1=\text { Believing that ICZM means managing the coast according } \\
\text { to its social, economic, and environmental aspects; }\end{array}$ & 29.91 \\
\hline & $0=$ otherwise & 37.38 \\
\hline $\begin{array}{l}\text { Satisfied with regional } \\
\text { coastal management }\end{array}$ & $\begin{array}{l}1 \text { = Being satisfied with the regional and local coastal } \\
\text { management; } 0=\text { otherwise }\end{array}$ & 62.62 \\
\hline In favour of the project & $\begin{array}{l}1=\text { Being in favour of the beach defence project; } \\
0=\text { otherwise }\end{array}$ & 82.24 \\
\hline Compulsory schooling & $1=$ Having had schooling up to the age of $14 ; 0=$ otherwise & 44.86 \\
\hline Secondary education & $1=$ Having had schooling up to the age of $18 ; 0=$ otherwise & 49.53 \\
\hline University Degree & $\begin{array}{l}1=\text { Having a university degree; } 0=\text { otherwise } \\
\text { (reference category) }\end{array}$ & 5.61 \\
\hline Aged 18-30 & $1=18-30$ years old; $0=$ otherwise (reference category) & 6.54 \\
\hline Aged 31-40 & $1=31-40$ years old $; 0=$ otherwise & 24.30 \\
\hline Aged 41-50 & $1=41-50$ years old $; 0=$ otherwise & 28.97 \\
\hline Aged over 50 & $1=51$ years old and over; $0=$ otherwise & 40.19 \\
\hline
\end{tabular}

